\title{
PENGARUH MODEL PEMBELAJARAN TIME TOKEN BERBANTUAN MEDIA VIDEO TERHADAP HASIL BELAJAR IPA KELAS V SD
}

\author{
I Putu Yoga Pramana \\ Universitas Pendidikan Ganesha \\ Email:yogapramana85@gmail.com
}

I Made Suarjana

Universitas Pendidikan Ganesha Email:pgsd_undiksha@yahoo.co.id

\begin{abstract}
Abstrak
Permasalahan rendahnya hasil belajar IPA dengan rata-rata 65,95 disebabkan karena pembelajaran lebih banyak menggunakan metode ceramah dan penugasan, sehingga siswa terlihat bosan ketika mengikuti pembelajaran. Penelitian ini bertujuan untuk mengetahui pengaruh signifikan model pembelajaran Time Token berbantuan media video terhadap hasil belajar IPA pada siswa kelas V SD Gugus I Kecamatan Tegallalang Kabupaten Gianyar Tahun Pelajaran 2017/2018. Jenis peneltian ini adalah penelitian eksperimen semu, populasi penelitian siswa kelas V SD Gugus I Kecamatan Tegalalang Kabupaten Gianyar Tahun Pelajaran 2017/2018 yang berjumlah 131 siswa. Sampel penelitian ini yaitu kelas V SD Negeri 1 Tegallalang yang berjumlah 35 siswa dan siswa kelas V SD Negeri 5 Tegallang yang berjumlah 33 siswa. Data hasil belajar IPA dikumpulkan dengan menggunakan tes yaitu dengan tes objektif. Data yang diperoleh dianalisis dengan menggunakan teknik analisis statistik deskriptif. Dengan analisis statistik deskriptif pada kelompok eksperimen didapatkan mean (M) sebesar 23,26, median (Me) sebesar 24, dan modus (Mo) sebesar 26, selanjutnya analisis statistik deskriptif kelompok kontrol didapatkan mean (M) sebesar 14,94 median (Me) sebesar 14, dan modus (Mo) sebesar13. Berdasarkan analisis data dengan uji-t, dapat diketahui thit $=15,127$ dan ttab $=1,980$ untuk $\mathrm{db}=66$ pada taraf signifikansi 5\%. Berdasarkan kriteria pengujian, karena thit > ttab maka H0 ditolak dan H1 diterima. Dengan demikian dapat disimpulkan bahwa model pembelajaran Time Token berbantuan media video berpengaruh signifikan terhadap hasil belajar IPA pada Siswa kelas V SD Gugus I Tegallalang Kabupaten Gianyar Tahun pelajaran 2017/2018.
\end{abstract}

Kata kunci: hasil belajar, IPA, Time Token.

\begin{abstract}
The problem of low learning outcomes of science with an average of 65,95 is due to more learning using lecturing and assignment methods, so students look bored when following the lesson. This study aims to determine the significant influence of learning model Time Token assisted video media on science learning outcomes in grade V students SD Gugus I Kecamatan Tegallalang Kabupaten Gianyar Lessons Year 2017/2018. This type of research is a quasiexperimental research, research population of students of grade V SD Gugus I Kecamatan Tegalalang Kabupaten Gianyar Lessons Year 2017/2018 which amounted to 131 students. The sample of this research is class V SD Negeri 1 Tegallalang which amounted to 35 students and students of class V SD Negeri 5 Tegallang which amounted to 33 students. The data of science study was collected by using test with objective test. The data obtained were analyzed using descriptive. By descriptive statistic analysis in the experimental group, mean (M) is 23,26 , median (Me) is 24 , and mode (Mo) is 26 , then descriptive statistic analysis of control group got mean (M) equal to 14,94 median (Me ) of 14, and mode (Mo) of 13 . Based on data analysis with t-test, it can be known thit $=15,127$ and ttab $=1,980 \mathrm{for} \mathrm{db}=66$ at $5 \%$ significance level. Based on the test criteria, because thit> ttab then $\mathrm{H} 0$ is rejected and $\mathrm{H} 1$ accepted. Thus it can be concluded that Time Token learning model assisted by video media have a significant effect on science learning outcomes in Grade V SD Gugus I Kecamatan Tegallalang Kabupaten Gianyar Year lesson 2017/2018.
\end{abstract}

Keywords: learning outcomes, science, Time Token. 


\section{Pendahuluan}

Sekolah sebagai salah satu lembaga pendidikan, merupakan tempat untuk mengembangkan ilmu pengetahuan peserta didik yang selanjutnya akan diterapkan di masyarakat. Sekolah secara sistematis merencanakan bermacam-macam lingkungan, yakni pendidikan yang menyediakan berbagai kesempatan bagi siswa untuk melakukan berbagai kegiatan belajar yang dilaksanakan dalam bentuk proses pembelajaran (Hamalik, 2012).

Sekolah Dasar (SD) merupakan awal pendidikan formal di Indonesia. Pada jenjang SD, siswa akan dilatih dan diajarkan berbagai cara untuk mengubah pola tingkah laku mereka dari tidak bisa menjadi bisa, ataupun dari tidak tahu menjadi mengetahui sesuatu. Perubahan itu terjadi baik dari segi kognitif, afektif, maupun psikomotor. Penyelenggaraan pendidikan di SD bertujuan untuk memberikan bekal "kemampuan dasar membaca, menulis, menghitung, pengetahuan, dan keterampilan dasar yang bermanfaat bagi siswa sesuai dengan tingkat perkembangan, serta mempersiapkan mereka untuk mengikuti pendidikan selanjutnya"' (Susanto, 2013:89).

Pada jenjang pendidikan SD terdapat beberapa mata pelajaran yang diajarkan kepada siswa, salah satunya adalah Ilmu Pengetahuan Alam (IPA). IPA merupakan "usaha manusia dalam memahami alam semesta melalui pengamatan yang tepat (corret) pada sasaran serta menggunakan prosedur yang benar (true), dan dijelaskan dengan penalaran yang sahih (valid) sehingga menghasilkan kebutuhan yang betul (truth)" (Sutrisno, dkk: 2008:19). Susanto (2013) hakikat pembelajaran IPA dapat diklasifikasikan menjadi IPA sebagai proses, produk, dan sikap. Bundu (2006) hasil belajar IPA pada jenjang SD hendaknya mencakup hal-hal berikut, a) penguasaan proses ilmiah atau proses sains, b) penguasaan produk ilmiah atau produk sains, c) pembentukan sikap atau sikap sains. Berdasarkan hal tersebut, maka idealnya pembelajaran IPA SD tentunya tidak dilakukan secara instant tetapi melalui suatu proses dengan menggunakan sikap ilmiah. Melalui proses tersebut maka siswa tidak hanya mendengarkan penjelasan guru, akan tetapi siswa akan terlibat secara aktif dalam pelaksanaan proses pembelajaran.

Berdasarkan hasil observasi dan pencatatan dokumen yang ditemukan bahwa hasil belajar IPA SD Gugus I Kecamatan Tegallalang Kabupaten Gianyar masih belum maksimal. Hal ini dapat dilihat dari nilai rata-rata yang diperoleh dari nilai Ulangan Akhir Semester (UAS) pada tahun pelajaran 2017/2018 mata pelajaran IPA.

Berikut ditemukan hasil belajar siswa kelas V Gugus I Kecamatan Tegallalang Kabupaten Gianyar. Hal tersebut tercantum dari hasil UAS IPA Tahun Pelajaran 2017/2018 dapat dilihat pada Tabel 1 berikut.

Tabel 1.

Rata-rata Hasil Nilai UAS IPA Siswa Kelas V SD Gugus I Kecamatan Tegallalang Kabupaten Gianyar Tahun Pelajaran 2017/2018

\begin{tabular}{|c|c|c|c|c|c|c|}
\hline \multirow{2}{*}{ No } & \multirow{2}{*}{ Nama Sekolah } & \multirow{2}{*}{$\begin{array}{c}\text { Jumlah } \\
\text { Siswa }\end{array}$} & \multirow{2}{*}{ KKM } & \multicolumn{2}{|c|}{ Jumlah } & \multirow[t]{2}{*}{ Rata-rata Nilai UAS } \\
\hline & & & & $\mathbf{T}$ & TT & \\
\hline 1. & SDN 1 Tegallalang & 35 & 75 & 8 & 27 & 69,48 \\
\hline 2. & SDN 3 Tegallalang & 16 & 75 & 3 & 13 & 68,93 \\
\hline 3. & SDN 4 Tegallalang & 23 & 75 & 3 & 20 & 63,08 \\
\hline 4. & SDN 5 Tegallalang & 33 & 75 & 2 & 31 & 62,96 \\
\hline 5. & SDN 6 Tegallalang & 24 & 75 & 6 & 18 & 65,96 \\
\hline
\end{tabular}

(Sumber: wali kelas V di SD Gugus I Kecamatan Tegallalang, 8 Desember 2017)

Data tersebut menunjukkan bahwa 5 (lima) SD Gugus I Kecamatan Tegallalang Kabupaten Gianyar nilai rata-rata dari UAS siswa masih di bawah KKM. Berdasarkan hasil observasi ditemukan beberapa permasalahan yang menyebabkan kurang maksimalnya hasil belajar IPA siswa kelas V SD Gugus I Kecamatan Tegallalang Kabupaten Gianyar diantaranya a) pada saat kegiatan pembelajaran guru lebih banyak menggunakan metode pembelajaran ceramah dan penugasan sehingga seringkali siswa terlihat bosan ketika mengikuti pembelajaran, b) siswa kurang memperhatikan penjelasan materi yang disampaikan oleh guru, c) siswa kurang aktif dan antusias dalam mengikuti pembelajaran, d) proses pembelajaran di kelas lebih banyak diarahkan kepada kemampuan siswa untuk menghafal informasi, sehingga proses pembelajaran yang dilaksanakan masih kurang memperhatikan ketiga dimensi dari IPA itu sendiri yaitu IPA sebagai proses, produk dan sikap.

Adanya permasalahan yang ditemukan dalam pembelajaran IPA tersebut, maka perlu diadakan upaya untuk menciptakan suasana belajar yang kondusif dan menyenangkan, sehingga membuat siswa menjadi aktif, partisipatif, dan termotivasi untuk belajar sehingga mampu meningkatkan hasil belajar siswa. Dilihat dari hal tersebut maka guru harus mampu mempersiapkan proses pembelajaran mulai dari perencanaan sampai pada pelaksanaan di dalam kelas.

(Suastra, 2009:49) menyatakan model pembelajaran dapat diartikan sebagai "kerangka konseptual yang digunakan sebagai pedoman dalam melakukan suatu kegiatan'. Hal ini berarti bahwa model pembelajaran 
merupakan kerangka konseptual yang menggambarkan prosedur secara sistematis dalam mengorganisasi pengalaman belajar untuk mencapai tujuan belajar tertentu. Kiat-kiat dalam merancang suatu pola yang digunakan sebagai pedoman dalam merencanakan pembelajaran di kelas sangatlah penting, dengan menggunkan model pembelajaran akan mengarahkan para guru dalam merancang pembelajaran untuk membantu siswa dalam proses pembelajaran, sehingga tujuan pembelajaran dapat tercapai. Pemilihan model pembelajaran yang menarik, inovatif, dan berpusat pada siswa yang disesuaikan dengan karakteristik siswa pada mata pelajaran akan mampu meningkatkan hasil belajar siswa.

Berdasarkan pemaparan tersebut, maka salah satu solusi yang bisa ditawarkan untuk membangkitakan keaktifan siswa dalam kegiatan pembelajaran adalah dengan cara menerapkan model pembelajaran Time Token. Model pembelajaran Time Token merupakan salah satu tipe pembelajaran kooperatif. Widodo (dalam Shoimin, 2013:216) menyatakan "model pembelajaran Time Token sangat tepat untuk pembelajaran struktur yang dapat digunakan untuk mengajarkan keterampilan sosial, untuk menghindari siswa mendominasi pembicaraan atau siswa diam sama sekali”. Menurut Shoimin (2014) model pembelajaran Time Token memiliki beberapa kelebihan yaitu: (1) mendorong siswa untuk meningkatkan inisiatif dan partisipasi, (2) siswa tidak mendominasi pembicaraan atau diam sama sekali, (3) siswa menjadi aktif dalam kegiatan pembelajaran. Model pembelajaran tersebut mengajak siswa untuk aktif sehingga tepat digunakan dalam pembelajaran IPA.

Model pembelajaran Time Token di kelas dapat diintegrasikan dengan berbantuan media video. Video dapat menarik perhatian siswa dan juga membangkitkan minat belajar siswa. Media video pembelajaran dapat diartikan sebagai segala format media elektronik yang digunakan untuk merangsang pikiran, perasaan, dan minat siswa untuk belajar melalui penayangan ide atau gagasan, pesan, dan informasi gambar-gambar bergerak.

Berdasarkan uraian latar belakang tersebut maka dilakukan penelitian dengan judul "Pengaruh Model Pembelajaran Time Token Berbantuan Media Video Terhadap Hasil Belajar IPA pada Siswa Kelas V SD Gugus I Kecamatan Tegallalang Kabupaten Gianyar Tahun Pelajaran 2017/2018.

\section{Metode}

Penelitian ini dilaksanakan di SD Gugus I Kecamatan Tegallalang Kabupaten Gianyar tahun pelajaran 2017/2018. Jenis penelitian ini adalah penelitian eksperimen semu (quasi experiment) karena tidak semua variabel yang muncul dalam kondisi eksperimen dapat diatur dan dikontrol secara ketat selama 24 jam. Populasi penelitian ini adalah siswa kelas V SD di Gugus I Kecamatan Tegallalang, dengan jumlah 131 siswa, dibagi menjadi 5 SD yaitu (1) SD Negeri 1 Tegallalang 35 siswa, (2) SD Negeri 3 Tegallalang 16 siswa, (3) SD Negeri 4 Tegallalang 23 siswa, (4) SD Negeri 5 Tegallalang 33 siswa dan (5) SD Negeri 6 Tegallalang 24 siswa. Penentuan sampel kelas dilakukan dengan teknik random sampling. Untuk mengetahui kesetaraan kemampuan akademik pada populasi penelitian maka dilakukan uji ANAVA terhadap data hasil belajar IPA siswa kelas V pada semester I (ganjil).

Data hasil belajar IPA semester I pada siswa SD kelas V tersebut dilakukan uji kesetaraan yang dianalisis dengan uji ANAVA. Dari hasil uji ANAVA yang dilakukan diperoleh ke-5 SD yang ada di Gugus I Kecamatan Tegallalang memiliki kemampuan akademik setara. Langkah selanjutnya ialah melakukan teknik random sampling terhadap kelima sekolah tersebut. Dari teknik random sampling dengan teknik undian diperoleh SD N 1 Tegallalang sebagai kelompok eksperimen dan SD Negeri 5 Tegallalang sebagai kelompok kontrol. Kelompok eksperimen diberikan pembelajaran menggunakan model pembelajaran time token berbantuan media video dan kelompok kontrol tidak diberikan menggunakan model pembelajaran time token berbantuan media. Desain Penelitian yang digunakan adalah post-test only kontrol group design. Pemilihan desain ini karena peneliti ingin mengetahui perbedaan hasil belajar IPA antara kelompok eksperimen dan kelompok kontrol, dengan menngunakan metode post-test.

Data yang dianalisis dalam penelitian ini adalah hasil belajar IPA ranah kognitif yang dikumpulkan melalui tes pilhan ganda. Tes tersebut telah di uji coba lapangan, sehingga teruji validitas dan reliabilitasnya. Hasil tes uji lapangan tersebut selanjutnya diberikan kepada siswa kelas eksperimen dan kontrol sebagai post-test.

Analisis data yang digunakan dalam penelitian ini yaitu analisis statistik deskriptif dan data dianalisis dengan menghitung nilai mean, median, modus, standar deviasi, varian, skor maksimum, dan skor minimum. Dalam penelitian ini data disajikan dalam bentuk kurva poligon. Sedangkan teknik yang digunakan untuk menganalisis data guna menguji hipotesis penelitian adalah uji-t. Untuk bisa melakukan uji hipotesis, ada beberapa persyaratan yang harus dipenuhi dan perlu dibuktikan. Persyaratan yang dimaksud yaitu: (1) data yang dianalisis harus berdistribusi normal, (2) kedua data yang dianalisis harus bersifat homogen. Untuk dapat membuktikan dan mememenuhi persyaratan tersebut, maka dilakukanlah uji prasyarat analisis dengan melakukan uji normalitas, dan uji homogenitas. 


\section{Hasil dan Pembahasan}

Pengukuran dilakukan setelah kelompok eksperimen diberikan perlakuan model pembelajaran time token berbantuan media video dan kelompok kontrol tidak diberikan perlakuan model pembelajaran time token berbantuan media video, sebanyak sepuluh kali pertemuan dengan materi ajar yang sama. Rekapitulasi hasil analisis data statistik deskriptif disajikan pada Tabel 2.

Tabel 2.

Deskripsi Data Hasil Belajar Kelompok Eksperimen dan Kelompok Kontrol

\begin{tabular}{ccc}
\hline Statistik & Kelompok Eksperimen & Kontrol \\
\hline Mean & 23,26 & 14,94 \\
\hline Median & 24 & 14 \\
\hline Modus & 26 & 13 \\
\hline Standar deviasi & 2,99 & 3,00 \\
\hline Skor minimum & 17 & 10 \\
\hline Skor maxsimum & 28 & 21 \\
\hline
\end{tabular}

Selanjutnya data hasil belajar IPA pada kelompok eksperimen dan kelompok kontrol disajikan ke dalam polygon seperti pada Gambar 1 dan 2.

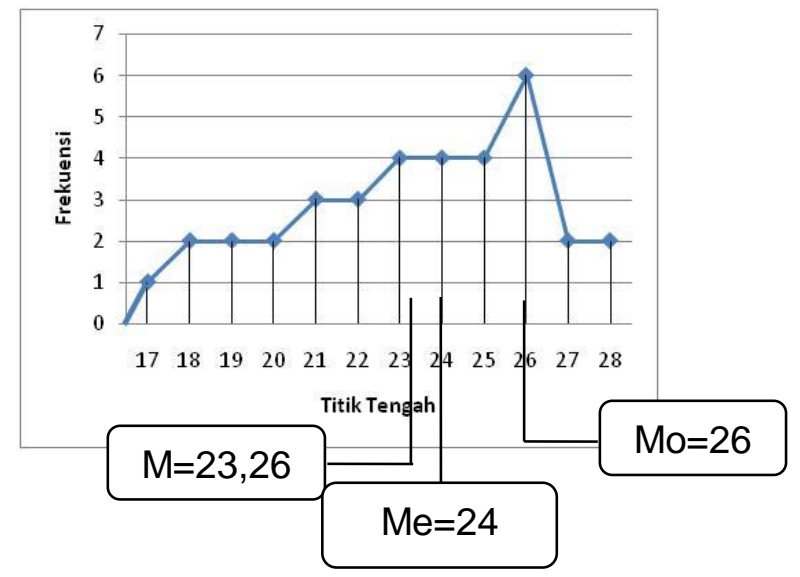

Gambar 1. Poligon Data Hasil Belajar IPA Kelompok Eksperimen

Berdasarkan Tabel 2 dapat diketahui bahwa modus (26) lebih besar dari median dan median (24) lebih besar dari mean $(23,26)(\mathrm{Mo}>\mathrm{Me}>\mathrm{M})$. Dengan demikian, polygon pada Gambar 1 membentuk kurva juling negatif yang berarti sebagian besar skor cenderung tinggi. Kecenderungan skor ini dapat dibuktikan dengan melihat frekuensi relatif pada tabel distribusi frekuensi. Frekuensi relatif skor yang berada di atas rata-rata lebih besar dibandingkan frekuensi relatif skor yang berada di bawah rata-rata. Untuk mengetahui kualitas variabel hasil belajar pada kelas eksperimen, skor rata-rata hasil belajar siswa dikonversikan menggunakan kriteria rata-rata ideal $\left(\mathbf{M}_{\mathrm{i}}\right)$ dan standar deviasi ideal $\left(\mathrm{SD}_{\mathrm{i}}\right)$.

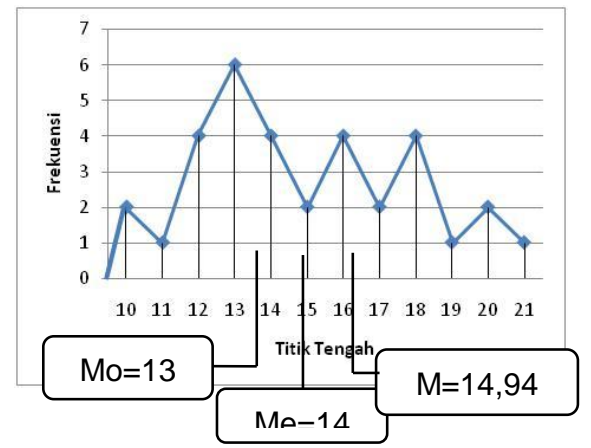

Gambar 2. Poligon Data Hasil Belajar IPA Kelompok Kontrol 
Berdasarkan Tabel 2 dapat diketahui bahwa modus (13) lebih kecil dari median dan median (14) lebih kecil dari mean $(14,94)(\mathrm{Mo}<\mathrm{Me}<\mathrm{M})$. Dengan demikian, poligon pada Gambar 2 membentuk kurva juling positif yang berarti sebagian besar skor cenderung rendah. Kecenderungan skor ini dapat dibuktikan dengan melihat frekuensi relatif pada tabel distribusi frekuensi. Frekuensi relatif skor yang berada di atas rata-rata lebih kecil dibandingkan frekuensi relatif skor yang berada di bawah rata-rata. Untuk mengetahui kualitas variabel hasil belajar pada kelas kontrol, skor rata-rata hasil belajar siswa dikonversikan menggunakan kriteria rata-rata ideal $\left(\mathbf{M}_{\mathrm{i}}\right)$ dan standar deviasi ideal $\left(\mathrm{SD}_{\mathrm{i}}\right)$.

Sebelum melakukan uji hipotesis maka harus dilakukan beberapa uji prasyarat terhadap sebaran data yang meliputi uji normalitas dan uji homogenitas terhadap data tes hasil belajar IPA siswa.

Uji normalitas sebaran data dilakukan untuk mengetahui apakah data yang diperoleh berdistribusi normal atau tidak. Jika berdistribusi normal maka uji hipotesis dapat dilakukan. Uji normalitas dalam penelitian ini menggunakan uji Chi Kuadrat (X2) dengan kriteria data berdistribusi normal jika $\mathrm{X}^{2}$ hitung $<\mathrm{X}^{2}$ tabel. Pengujian hipotesisnya yaitu H0: sampel berasal dari data yang berdistribusi normal dan H1: sampel berasal dari data yang tidak berdistribusi normal.

Uji normalitas data dilakukan terhadap data hasil belajar IPA kelompok eksperimen dan kontrol. Berdasarkan analisis data yang dilakukan dengan menggunakan program Microsoft Office Excel 2007 for Windows, dapat disajikan hasil uji normalitas sebaran data hasil belajar IPA kelompok eksperimen dan kontrol pada Tabel 3 berikut.

Tabel 3.

Hasil Uji Normalitas Sebaran Data

\begin{tabular}{llccc}
\hline No & Kelompok Data Hasil Belajar IPA & $\mathrm{X}^{2}{ }_{\text {hit }}$ & $\mathrm{X}_{\text {tab }}$ & Status \\
\hline 1 & Post-test Eksperimen & 5,493 & 16,919 & Normal \\
\hline 2 & Post test Kontrol & 7,399 & 16,919 & Normal \\
\hline
\end{tabular}

Kriteria pengujian, jika $\mathrm{X}^{2}$ hit $<\mathrm{X}_{\text {tab }}^{2}$ dengan taraf signifikasi $5 \%$ (dk = jumlah kelas dikurangi parameter, dikurangi 1), maka data berdistribusi normal. Sedangkan, jika $\mathrm{X}^{2}{ }_{\text {hit }} \geq \mathrm{X}_{\text {tab }}^{2}$, maka sebaran data tidak berdistribusi normal. Berdasarkan hasil perhitungan degan menggunakan rumus chi-kuadrat, diperoleh $\mathrm{X}^{2}$ hit hasil post-test kelompok eksperimen adalah 5,493 dan $\mathrm{X}_{\text {tab }}^{2}$ dengan taraf signifikasi 5\% dan $\mathrm{db}=9$ adalah 16,919. Hal ini berarti, $\mathrm{X}^{2}{ }_{\text {hit }}$ hasil post-test kelompok eksperimen lebih kecil dari $\mathrm{X}_{\text {tab }}^{2}\left(\mathrm{X}^{2}{ }_{\text {hit }}<\mathrm{X}_{\text {tab }}^{2}\right.$, sehingga data hasil post-test kelompok eksperimen berdistribusi normal. Sedangkan, $\mathrm{X}^{2}$ hit hasil post-test kelompok kontrol adalah 7,399 dan $\mathrm{X}_{\text {tab }}^{2}$ dengan taraf signifikansi $5 \%$ dan $\mathrm{db}=9$ adalah 16,919. Hal ini berarti, $\mathrm{X}^{2}$ hit hasil post-test kelompok kontrol lebih kecil dari $\mathrm{X}_{\text {tab }}^{2}\left(\mathrm{X}_{\text {hit }}^{2}<\mathrm{X}_{\text {tab }}^{2}\right.$, sehingga data hasil post-test kelompok kontrol berdistribusi normal.

Selanjutnya uji homogenitas dilakukan terhadap varians pasangan antar kelompok eksperimen dan kontrol. Uji yang digunakan adalah uji-F dengan kriteria data homogen jika $F_{\text {hit }}<F_{\text {tab. Rekapitulasi hasil uji homogenitas }}$ varians antar kelompok eksperimen dan kontrol disajikan pada tabel 4 berikut.

Tabel 4.

Hasil Uji Homogenitas Varians antar Kelompok Eksperimen dan Kontrol

\begin{tabular}{lccccc}
\hline & Data & $F_{\text {hitung }}$ & $F_{\text {tabel }}$ & Kesimpulan \\
\hline $\begin{array}{l}\text { Post-Test } \\
\text { Kontrol }\end{array}$ & Kelompok Eksperimen dan Kelompok & 1,83 & 3,92 & Homogen \\
\hline
\end{tabular}

Berdasarkan tabel 4 hasil perhitungan $F_{\text {hitung }}$ hasil post-test kelompok eksperimen dan kontrol adalah 1,83. Selanjutnya harga $\mathrm{F}$ hitung tersebut dibandingkan dengan $\mathrm{F}$ tabel pada taraf signifikansi $5 \%$. Berdasarkan $\mathrm{F}$ tabel pada taraf signifikansi $5 \%$ dengan df1 $=\mathrm{k}-1=2-1=1$, dan df2 $=\mathrm{n}-\mathrm{k}=68-2=66$, didapatkan harga $\mathrm{F}$ tabel sebesar 3,92. Hasil tersebut menunjukan $\mathrm{F}$ hitung $<\mathrm{F}$ tabel, sehingga dapat disimpulkan bahwa kedua kelompok tersebut homogen.

Berdasarkan uji prasyarat analisis data, diperoleh bahwa data hasil post-test kelompok eksperimen dan kontrol adalah normal dan homogen. Setelah diperoleh hasil dari uji prasyarat analisis data, dilanjutkan dengan pengujian hipotesis penelitian $\left(\mathrm{H}_{1}\right)$ dan hipotesis nol $\left(\mathrm{H}_{0}\right)$.

Kriteria pengujian adalah tolak $\mathrm{H}_{0}$ jika $t_{\text {hit }}>\mathrm{t}_{\mathrm{tab}}$, dimana $\mathrm{t}_{\text {tab }}$ diperoleh dari tabel distribusi $\mathrm{t}$ pada taraf signifikansi $5 \%$ dengan derajat kebebasan $\mathrm{db}=\mathrm{n} 1+\mathrm{n} 2-2$. Rangkuman hasil analisis uji-t ditampilkan pada Tabel 5 berikut. 
Tabel 5.

Hasil Uji-T

\begin{tabular}{|c|c|c|c|c|c|c|}
\hline Kelompok & $\mathrm{N}$ & $\mathrm{Db}$ & Mean & $\mathrm{s}^{2}$ & $t_{\text {hit }}$ & $\mathrm{t}_{\mathrm{tab}}$ \\
\hline Eksperimen & 35 & \multirow{2}{*}{66} & 23,26 & 1,59 & \multirow{2}{*}{15,127} & \multirow{2}{*}{1,980} \\
\hline Kontrol & 33 & & 14,94 & 8,47 & & \\
\hline
\end{tabular}

Berdasarkan table 5 hasil perhitungan uji-t, diperoleh $t_{\text {hit }}$ sebesar 15,127 . Sedangkan, $t_{t a b}$ dengan db $=35$ $+33-2=66$ dan taraf signifikansi $5 \%$ adalah 1,980. Berdasarkan kriteria pengujian, karena $t_{\text {hit }}>t_{\text {tab }} m_{a k a} H_{0}$ ditolak dan $\mathrm{H}_{1}$ diterima. Artinya, terdapat pengaruh pada hasil belajar IPA antara kelompok siswa yang dibelajarkan dengan menggunakan model pembelajaran Time Token berbantuan media video dan kelompok siswa yang tidak dibelajarkan dengan menggunakan model pembelajaran Time Token pada siswa kelas V SD Gugus I Kecamatan Tegallalang Kabupaten Gianyar Tahun pelajaran 2017/2018.

\section{PEMBAHASAN}

Hasil analisis data menunjukkan bahwa terdapat pengaruh hasil belajar antara kelompok siswa yang dibelajarkan dengan model pembelajaran Time Token berbantuan media video dengan siswa yang tidak dibelajarkan dengan model pembelajaran Time Token berbantuan media video. Tinjauan ini didasarkan pada hasil uji-t dan rata-rata skor hasil belajar siswa. Analisis data menggunakan uji-t, diketahui $t_{\text {hit }}=15,127$ dan $t_{\text {tab }}$ pada taraf signifikansi $5 \%=1,980$. Hasil perhitungan tersebut menunjukkan bahwa $t_{\text {hit }}>t_{\text {tab }}$, sehingga hasil penelitian adalah signifikan. Hal ini berarti, terdapat perbedaan hasil belajar antara kelompok siswa yang dibelajarkan dengan model pembelajaran Time Token berbantuan media video dengan siswa yang tidak dibelajarkan model pembelajaran Time Token berbantuan media video.

Ngalimun (2012:248) mengemukakan bahwa "Time Token adalah salah satu model pembelajaran yang digunakan (Arends, 1998) untuk melatih dan mengembangkan keterampilan social agar siswa tidak mendominasi pembicaraan atau diam sama sekali". Sejalan dengan pendapat tersebut Kurniasih dan Sani (2016:183) menyatakan bahwa "model pembelajaran Time Token Arends merupakan salah satu contoh kecil dari penerapan pembelajaran demokratis di sekolah".

Jadi model pembelajaran Time Token merupakan suatu pembelajaran demokratis yang digunakan untuk melatih keterampilan sosial siswa, agar tidak mendominasi pembicaraan atau diam sama sekali dalam proses pembelajaran.

Menurut Shoimin (2014) model pembelajaran Time Token memiliki beberapa kelebihan yaitu: a) kelebihan model pembelajaran Time Token (1) mendorong siswa untuk meningkatkan inisiatif dan partisipasi, (2) siswa tidak mendominasi pembicaraan atau diam sama sekali, (3) siswa menjadi aktif dalam kegiatan pembelajaran, (4) meningkatkan kemampuan siswa dalam berkomunikasi, (5) melatih siswa mengungkapkan pendapatnya.

Hal ini berbeda dengan pembelajaran yang tidak menggunakan model pembelajaran Time Token berbantuan media video pada kelas kontrol. Pembelajaran yang mencirikan masih berpusat pada guru. Secara teoritis, pembelajaran tersebut adalah pembelajaran tradisional atau disebut juga dengan metode ceramah, karena sejak dulu metode ini telah dipergunakan sebagai alat komunikasi lisan antara guru dengan siswa dalam proses belajar dan mengajar. Dalam hal ini, terlihat bahwa pembelajaran kurang maksimal dalam meningkatkan hasil belajar siswa.

Dengan demikian hasil penelitian ini membuktikan bahwa model pembelajaran Time Token berbantuan media video memberikan pengaruh terhadap hasil belajar siswa. Tentu saja dalam hal ini hasil belajar siswa meningkat. Hal ini dapat dilihat dari pembelajaran Time Token berbantuan media video lebih banyak menekankan dalam inisiatif siswa dalam belajar serta aktif dalam proses pembelajaran sedangkan guru hanya bertugas sebagai fasilitator dan motivator dalam pembelajaran.

Hambatan yang ditemukan ketika dilakukan penelitian pada kelas eksperimen hanya ada beberapa hambatan kecil seperti masih terdapat beberapa siswa yang suka bercanda dan kurang fokus dalam mengikuti proses pembelajaran di kelas, tetapi hal tersebut sudah dapat ditanggulangi oleh guru dengan memberikan perhatian lebih kepada siswa yang bersangkutan. Sementara hambatan di kelas kontrol lebih banyak ditemukan. Hambatanhambatan tersebut adalah banyak ditemukan siswa yang kurang memperhatikan guru saat menjelaskan materi. Selain itu terdapat beberapa siswa yang bermain-main dengan temannya pada saat proses pembelajaran berlangsung.

Berdasarkan hasil penelitain tersebut dapat dikemukakan implikasi secara teoretis dan praktis adalah sebagai berikut.

Implikasi teoretis yaitu (a) pemilihan model pembelajaran yang tepat dapat berpengaruh terhadap peningkatan hasil belajar IPA siswa SD, (b) penelitian ini membuktikkan bahwa model pembelajaran Time Token berbantuan media video baik diterapkan dalam proses pembelajaran untuk meningkatkan hasil belajar IPA siswa di 
SD. Implikasi praktis yaitu berdasarkan hasil penelitian ini dapat digunakan sebagai masukan bagi guru untuk membenahi proses pembelajaran agar hasil belajar IPA siswa sesuai dengan tujuan pembelajaran. Model pembelajaran Time Token berbantuan media video dapat diterapkan guu saat pembelajaran IPA. Hal ini sudah terbukti bahwa dengan diterapkan model pembelajaran Time Token berbantuan media video dapat meningkatkan hasil belajar IPA siswa. Pembelajaran menggunakan model pembelajaran Time Token berbantuan media video membuat siswa lebih tertarik untuk mengikuti pembelajaran karena materi yang disampaikan oleh guru ditayangkan lewat video pembelajaran yang relevan dan inovatif. Sehingga siswa lebih mudah memahami materi yang dibelajarkan dan dapat meningkatkan hasil belajar IPA siswa.

\section{Simpulan dan Saran}

Adapun simpulan yang dapat disampaikan setelah melaksanakan dan memperoleh hasil dari penelitian adalah sebagai berikut.

Analisis data hasil belajar IPA kelompok eksperimen dengan jumlah sebanyak 35 siswa dengan nilai tertinggi yang diperoleh 28 dan nilai terendah adalah 17. Dari sebaran data tersebut diperoleh nilai rata-rata (mean) sebesar 23,26, data yang paling sering muncul (modus) adalah 26 dan nilai tengah (median) adalah 24. Berdasarkan hasil konversi, diperoleh bahwa skor rata-rata hasil belajar IPA siswa kelompok eksperimen, dengan = 23, 26 tergolong kriteria "Sangat tinggi". Selanjutnya analisis data hasil belajar IPA kelompok kontrol dengan jumlah sebanyak 33 siswa dengan nilai tertinggi yang diperoleh 21 dan nilai terendah adalah 12. Dari sebaran data tersebut diperoleh rata-rata (mean) sebesar 14,94, data yang paling sering muncul (modus) adalah 13 dan nilai tengah (median) adalah 14.Berdasarkan hasil konversi, diperoleh bahwa skor rata-rata hasil belajar IPA siswa kelompok kontrol, dengan $=14,94$ tergolong kriteria "Sedang".

Berdasarkan hasil analisis data diperoleh thit $=15,127$ sedangkanttab pada taraf signifikansi $5 \%$ dan $\mathrm{db}=$ $\mathrm{n} 1+\mathrm{n} 2-2=(35+33-2)=66$ adalah 1,980 , sehingga thitung $=15,127>$ ttabel $=1,980$ maka H0 ditolak dan H1 diterima. Perbedaan hasil belajar IPA antara kelompok siswa yang dibelajarkan dengan model pembelajaran Time Token berbantuan media video dengan kelompok siswa yang tidak dibelajarkan dengan menggunakan model pembelajaran Time Token berbantuan media video $(23,26>14,94)$. Dengan demikian dapat disimpulkan bahwa model pembelajaran Time Token berbantuan media video berpengaruh signifikan terhadap hasil belajar IPA pada Siswa kelas V SD Gugus I Tegallalang Kabupaten Gianyar Tahun pelajaran 2017/2018.

\section{Saran}

Saran yang diharapkan dari penelitian yang telah dilakukan sebagai berikut. Secara Teoretis, penelitian ini dapat memberikan kontribusi mengenai model pembelajaran yang inovatif untuk menunjang proses pembelajaran di. Selain itu, terdapat saran terhadap beberapa pihak yaitu: (1) bagi siswa di sekolah dasar agar dapat mengembangkan rasa ingin tahu dalam memperoleh pengetahuan serta mengatasi rasa malu dengan cara ikut berperan aktif selama pembelajaran berlangsung, (2) bagi guru di sekolah dasar hendaknya lebih berinovasi dalam pembelajaran salah satunya dengan model pembelajaran Time Token berbantuan media video untuk dapat meningkatkan motivasi dan keaktifan siswa dalam pembelajaran sehingga hasil belajar meningkat, sebab telah terbukti pada penelitian ini bahwa terdapat perbedaan hasil belajar yang antara kelompok siswa yang belajar dengan model pembelajaran Time Token berbantuan media video dengan kelompok siswa yang tidak dibelajarkan dengan model pembelajaran Time Token berbantuan media video, (3) bagi kepala sekolah hendaknya mengikutsertakan guru-guru dalam pelatihan mengenai pembelajaran inovatif dan mengupayakan untuk menambah media pembelajaran yang relevan dengan pembelajaran di sekolah, (4) bagi peneliti yang berminat untuk mengadakan penelitian lebih lanjut tentang model pembelajaran Time Token berbantuan media video dalam bidang pendidikan khususnya pada mata pelajaran IPA agar memperhatikan kendala-kendala yang dialami dalam penelitian ini sebagai bahan petimbangan untuk perbaikan dan penyempurnaan penelitian yang akan dilaksanakan.

\section{Ucapan Terimakasih}

Artikel ini disusun guna memenuhi persyaratan mencapai gelar sarjana pendidikan pada Universitas Pendidikan Ganesha dan artikel ini dapat diselesaikan tepat pada waktunya. Dalam menyelesaikan artikel ini, banyak didapatkan bantuan dan bimbingan baik berupa moral maupun material dari berbagai pihak. Untuk itu dalam kesempatan ini, diucapkan rasa hormat serta rasa terima kasih kepada: Prof. Dr. Ni Ketut Suarni, M.S. Kons, selaku Dekan Fakultas Ilmu Pendidikan, Universitas Pendidikan Ganesha yang telah mengesahkan skripsi yang diajukan guna memenuhi syarat-syarat untuk mencapai gelar sarjana pendidikan. Dr Desak Putu Parmiti, M.S., selaku Ketua Jurusan Pendidikan Guru Sekolah Dasar, Fakultas Ilmu Pendidikan, Universitas Pendidikan Ganesha yang telah menyetujui judul penelitian dalam artikel ini. Prof. Dr. Anak Agung Gede Agung, M.Pd. selaku Pembimbing I yang telah banyak memberikan bimbingan, pengalaman, pengetahuan, arahan, petunjuk serta dukungan selama penyusunan artikel ini sehingga artikel ini dapat terselesaikan. Drs. I Made Suarjana, M.Pd. 
selaku Pembimbing II yang telah memberikan bimbingan, pengalaman, pengetahuan, arahan, petunjuk serta dukungan selama penyusunan artikel ini sehingga artikel ini dapat terselesaikan. I Wayan Subaga S.Pd. SD. selaku kepala SD Negeri 1 Tegallalang yang telah memberikan ijin untuk melaksanaan penelitian di sekolah yang dipimpinnya. Ni Putu Nuryeni, S.Pd,. M.Pd. H. selaku kepala SD Negeri 5 Tegallalang yang telah memberikan ijin untuk melaksanaan penelitian di sekolah yang dipimpinnya. Sang Ayu Putu Ariani, S.Pd. selaku guru kelas dan bidang studi IPA di kelas V SD Negeri 1 Tegallalang yang telah sabar meluangkan waktu untuk dapat bekerjasama, serta memberikan informasi sehingga penelitian ini dapat terlaksana dengan baik. Ni Made Rai Ukirani, S.Pd. selaku guru kelas dan bidang studi IPA di kelas V SD Negeri 5 Tegallalang yang telah sabar meluangkan waktu untuk dapat bekerjasama, serta memberikan informasi sehingga penelitian ini dapat terlaksana dengan baik. Bapak/ibu dan stap pegawai di lingkungan SD Gugus I Tegallalang yang telah memberikan bantuan dan dukungan dalam memperlancar penelitian ini. Seluruh siswa-siswi kelas V SD Gugus I Tegallalang yang telah tekun berpartisipasi dan mengikuti secara langsung penelitian ini. Seluruh rekan-rekan mahasiswa yang telah membantu memberi dukungan dan motivasi selama penyusunan artikel ini. Orang tua dan keluarga yang telah memberikan dukungan moral dan materil selama perkulihan hingga penyusunan skripsi.

\section{Daftar Pustaka}

Bundu, P. 2006. Penilaian Keterampilan Proses dan Sikap Ilmiah Dalam Pembelajaran Sain SD. Jakarta: Departemen Pendidikan Nasional Direktorat Jendral Pendidikan Tinggi Direktorat Ketenagaan.

Hamalik, O.2012. Kurikulum dan Pembelajaran. Jakarta: PT Bumi Aksara.

Ngalimun. 2012. Strategi dan Model Pembelajaran. Yogyakarta: Aswaja Pressindo.

Shoimin, Aris. 2014. 68 Model Pembelajaran Inovatif dalam Kurikulum 2013. Yogyakarta: Ar-Ruzz Media.

Suastra, I.W. 2009. Pembelajaran Sains Terkini. Singaraja: Undiksha.

Susanto, Ahmad. 2013. Teori Belajar dan Pembelajaran di Sekolah Dasar. Jakarta: Kencana Prenadamedia Group.

Sutrisno, L., dkk. 2008. Pengembangan Pembelajaran IPA SD. Jakarta: Direktorat Jendral Pendidikan Tinggi Departemen Pendidikan Nasional. 